\title{
Hepatitis C eradication and improvement of cryoglobulinemia-associated rash and membranoproliferative glomerulonephritis with interferon and ribavirin after kidney transplantation
}

\author{
Marilyn Zeman $\mathrm{MD}^{1}$, Patricia Campbell $\mathrm{MBChB}^{2}$, Vincent G Bain $\mathrm{MD}^{1}$
}

\begin{abstract}
M Zeman, P Campbell, VG Bain. Hepatitis C eradication and improvement of cryoglobulinemia-associated rash and membranoproliferative glomerulonephritis with interferon and ribavirin after kidney transplantation. Can J Gastroenterol 2006;20(6):427-431.
\end{abstract}

Postrenal transplant hepatitis $\mathrm{C}$ is increasing in frequency due to the high prevalence of hepatitis $\mathrm{C}$ among patients with renal failure. Despite this, there is still no standard hepatitis $\mathrm{C}$ treatment available for renal transplanted recipients. Combination antiviral hepatitis $\mathrm{C}$ therapy, the standard of care in the nontransplant population, is generally avoided because of documented renal graft rejection secondary to interferon treatment. A case of a male patient with postrenal transplant hepatitis $\mathrm{C}$, which was associated with cryoglobulinemia and glomerulonephritis of the graft, is presented. He was treated with standard interferon with ribavirin. Sustained viral clearance was achieved despite ongoing evidence of cryoglobulinemia. Renal function, which had been deteriorating before treatment, improved as evidenced by the stabilization of serum creatinine and marked improvement of proteinuria. In conclusion, in selected patients, combination antiviral therapy may still be a viable option postrenal transplant.

Key Words: Cryoglobulin; Hepatitis C; Interferon; Kidney transplant
L'éradication de l'hépatite $\mathrm{C}$ et l'atténuation de l'éruption associée à la cryoglobulinémie et à la glomérulonéphrite membranoproliférative grâce à l'interféron et à la ribavirine après une greffe du rein

La fréquence d'hépatites $\mathrm{C}$ après une greffe du rein augmente en raison de la forte prévalence des cas d'hépatite $\mathrm{C}$ chez les patients atteints d'insuffisance rénale. Pourtant, il n'existe toujours pas de traitement universel contre l'hépatite $\mathrm{C}$ à l'intention des greffés du rein. On évite généralement la polythérapie de l'hépatite $\mathrm{C}$ aux antiviraux, la norme des soins au sein de la population non greffée, en raison du rejet documenté du greffon rénal secondaire au traitement à l'interféron. Est présenté le cas d'un patient de sexe masculin atteint d'une hépatite $\mathrm{C}$ après une greffe du rein associée à une cryoglobulinémie et à une glomérulonéphrite du greffon. Il a été traité par un traitement standard à l'interféron et à la ribavirine. On a obtenu une clairance virale soutenue malgré la présence constante et démontrée de cryoglobulinémie. La fonction rénale, qui se détériorait avant le traitement, a progressé, comme le démontre l'amélioration de la protéinurie. En conclusion, chez certains patients, une polythérapie antivirale peut constituer une possibilité viable après une greffe du rein.
T iver disease due to hepatitis $\mathrm{C}$ virus (HCV) postrenal trans-

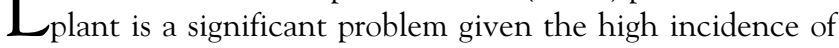
HCV in patients with kidney diseases (1). Furthermore, immunosuppression can have an adverse effect on the progression of HCV. HCV can also affect the renal graft due to the development of glomerulonephritis. The treatment of chronic HCV liver or kidney disease includes combination antiviral therapy with pegylated interferon-alpha (PEGIFN- $\alpha$ ) and ribavirin (2,3). However IFN- $\alpha$ (both standard and PEG) treatment has generally been avoided in the renal transplant population because of the frequent occurrence of acute graft failure secondary to rejection (4). Ribavirin alone lowers HCV RNA levels but cannot clear the virus (5). In nontransplant studies, the addition of ribavirin to PEGIFN- $\alpha$ has increased the rate of sustained viral response (SVR), defined as the absence of HCV RNA in serum at the end of treatment and six months later, from 29\% (PEGIFN- $\alpha$ alone) to $56 \%$ (PEGIFN- $\alpha$ and ribavirin) (3). In renal insufficiency, ribavirin is contraindicated due to reduced clearance of the drug and the risk of severe hemolytic anemia. However, newer evidence does support its use in moderate to severe renal disease with diligent therapeutic drug monitoring, careful ribavirin dosing and erythropoietin use $(6,7)$.

We describe a case of postrenal transplant chronic HCV glomerulopathy associated with cryoglobulinemia treated with combination IFN- $\alpha$ and ribarivin therapy with resulting improvement in renal dysfunction, lack of transplant rejection and clearance of $\mathrm{HCV}$.

\section{CASE PRESENTATION}

A 44-year-old man with end-stage renal disease secondary to membranoproliferative glomerulonephritis (MPGN) associated with cryoglobulinemia presented in September 1998 after testing positive for $\mathrm{HCV}$, genotype $2 \mathrm{~b}$. He had been on peritoneal dialysis for 18 months and was being considered for renal transplant. His HCV was thought to be secondary to intravenous drug use between 1975 and 1978, and his only symptoms were those of cryoglobulinemia. These included a recurrent,

${ }^{1}$ Division of Gastroenterology; ${ }^{2}$ Division of Nephrology, Department of Medicine, University of Alberta, Edmonton, Alberta

Correspondence: Dr Vincent G Bain, Zeider Ledcor Centre, 130 University Campus, Edmonton, Alberta T6G 2X8.

Telephone 780-492-8128, fax 780-492-8130, e-mail vince.bain@ualberta.ca

Received for publication July 3, 2005. Accepted December 5, 2005 
raised pruritic rash on the lower extremities and mild arthralgia. Past medical history showed primary hypertension for 10 years. His medications included diltiazem sustained release $90 \mathrm{mg}$ taken orally twice a day; terazosin $10 \mathrm{mg}$ taken orally daily; prazosin, one tablet taken orally twice a day; prednisone $10 \mathrm{mg}$ taken orally twice a day (for treatment of his vasculitis rash on the lower extremeties); furosemide $40 \mathrm{mg}$ taken orally daily; calcitriol, one tablet taken orally daily; calcium carbonate $1000 \mathrm{mg}$ taken orally daily; ranitidine $150 \mathrm{mg}$ taken orally daily; epoetin alfa (Eprex, Janssen-Ortho, Canada) $50 \mathrm{IU} / \mathrm{kg}$ to $100 \mathrm{IU} / \mathrm{kg}$ taken subcutaneously twice a day; and a daily multivitamin.

On physical examination, his blood pressure was unusually high at 210/105 $\mathrm{mmHg}$ with no evidence of cardiac, cerebral or retinal sequelae. His abdomen was soft and nontender with no evidence of hepatomegaly or splenomegaly. Peripheral examination revealed bilateral stasis dermatitis in the lower extremities secondary to recurrent purpuric vasculitis. A skin biopsy performed the year before presentation had shown leukocytoclastic vasculitis, which was immunoglobulin- and complement-negative.

Laboratory results showed a normal complete blood count with a hemoglobin of $133 \mathrm{~g} / \mathrm{L}$ (normal values $135 \mathrm{~g} / \mathrm{L}$ to $175 \mathrm{~g} / \mathrm{L}$ ). Renal function revealed an elevated creatinine at $584 \mu \mathrm{mol} / \mathrm{L}$ (normal values $45 \mu \mathrm{mol} / \mathrm{L}$ to $125 \mu \mathrm{mol} / \mathrm{L}$ ) with a blood urea nitrogen of $24.9 \mathrm{mmol} / \mathrm{L}$ (normal values $2.5 \mathrm{mmol} / \mathrm{L}$ to $8.0 \mathrm{mmol} / \mathrm{L}$ ). Calcium was normal at $2.52 \mathrm{mmol} / \mathrm{L}$ (normal values $2.10 \mathrm{mmol} / \mathrm{L}$ to $2.60 \mathrm{mmol} / \mathrm{L}$ ) with an elevated phosphate level at $1.93 \mathrm{mmol} / \mathrm{L}$ (normal values $0.80 \mathrm{mmol} / \mathrm{L}$ to $1.45 \mathrm{mmol} / \mathrm{L}$ ) and a normal alkaline phosphate level of $91 \mathrm{U} / \mathrm{L}$ (normal values $30 \mathrm{U} / \mathrm{L}$ to $130 \mathrm{U} / \mathrm{L}$ ). Liver enzymes and function tests included an alanine transferase (ALT) level of $28 \mathrm{U} / \mathrm{L}$ (normal value less than $50 \mathrm{U} / \mathrm{L}$ ), albumin $28 \mathrm{~g} / \mathrm{L}$ (normal values $35 \mathrm{~g} / \mathrm{L}$ to $50 \mathrm{~g} / \mathrm{L}$ ), total bilirubin $8 \mu \mathrm{mol} / \mathrm{L}$ (normal values less than $20 \mu \mathrm{mol} / \mathrm{L}$ ) and an international normalized ratio of 1.0 (normal values 0.8 to 1.2 ). Fasting lipid profile showed evidence of a mild increase in both cholesterol at $6.59 \mathrm{mmol} / \mathrm{L}$ and triglycerides at $6.96 \mathrm{mmol} / \mathrm{L}$. Urinalysis revealed $3+$ proteinuria, $1+$ hemoglobin and cytodiagnostic evidence of coarse granular casts. A kidney biopsy performed at that time showed pauci-immune MPGN related to a type II cryoglobulinemia. The patient was HIV, antinuclear antibody and rheumatoid factor-negative. Protein serum electrophoresis was normal. C3 levels were borderline low at $0.77 \mathrm{~g} / \mathrm{L}$ (normal values $0.80 \mathrm{~g} / \mathrm{L}$ to $2.0 \mathrm{~g} / \mathrm{L}$ ) and $\mathrm{C} 4$ levels were normal at $0.25 \mathrm{~g} / \mathrm{L}$ (normal values $0.18 \mathrm{~g} / \mathrm{L}$ to $0.36 \mathrm{~g} / \mathrm{L}$ ).

The decision was made to attempt HCV clearance before renal transplantation and standard IFN $-\alpha 3 \mathrm{mU}$ administered subcutaneously three times a week was initiated. This was subsequently decreased to $1.5 \mathrm{mU}$ three times a week within two months because the patient developed anxiety, shakiness and blurry vision. The patient was eventually able to tolerate $2 \mathrm{mU}$ three times a week. Ribavirin was never started because of renal failure. At the end of 12 months of IFN- $\alpha$ treatment, the patient was HCV RNA-negative and all his vasculitic lesions had completely disappeared, despite still being serum cryoglobulinpositive. During this time, his medications remained the same except that prazosin had been discontinued and fosinopril (Monopril, Bristol-Myers Squibb, Canada) $20 \mathrm{mg}$ taken orally twice a day had been started. Prednisone had been decreased from $10 \mathrm{mg}$ orally twice a day to $5 \mathrm{mg}$ orally daily. Four months later, he was again found to be HCV RNA-positive with a HCV 2 b RNA level greater than $8.5 \times 10^{5}$ IU/L (no further dilutions were performed in view of favourable HCV genetic profile) with minor recurrence of the vasculitic rash. By that time, peritoneal dialysis had failed secondary to peritonitis and hemodialysis had been initiated and the patient remained consistently adamant that he wanted to undergo renal transplantation despite risk of recurrent disease.

The patient underwent renal transplantation, receiving a kidney from an HCV genotype 2b-positive cadaveric donor. Immunosuppression consisted of tacrolimus targeted to a serum level of $12 \mu \mathrm{g} / \mathrm{L}$ to $15 \mu \mathrm{g} / \mathrm{L}$ immediately post-transplant, which was tapered down to $5 \mu \mathrm{g} / \mathrm{L}$ to $7 \mu \mathrm{g} / \mathrm{L}$; mycophenolate mofetil (Cellcept, Hoffmann-La Roche Ltd, Canada) $1 \mathrm{~g}$ taken twice a day; and prednisone. The prednisone has never been fully tapered off and remains at least at $6.5 \mathrm{mg}$ taken orally daily so that he could remain rash free. Baseline creatinine was $97 \mu \mathrm{mol} / \mathrm{L}$ (normal values $45 \mu \mathrm{mol} / \mathrm{L}$ to $125 \mu \mathrm{mol} / \mathrm{L}$ ) by one year posttransplant. Urine protein to creatinine ratio and ALT levels remained normal. Treatment of his recurrent $\mathrm{HCV}$ ( $\mathrm{HCV} 2 \mathrm{~b}$ RNA level greater than $8.5 \times 10^{5} \mathrm{IU} / \mathrm{L}$ ) was initially withheld because liver function remained unaffected and IFN- $\alpha$ would increase his risk of rejection. Over the course of the next year, renal function deteriorated despite adequate immunosuppression and avoidance of additional nephrotoxic agents. A renal allograft biopsy performed 20 months post-transplant showed no evidence of graft rejection; however, there was noted absence of immunoglobulin $\mathrm{G}$ consistent with MPGN from HCV. Furthermore, the pathology was noted to be similar to that seen pretransplant, which is also consistent with $\mathrm{HCV}$ recurrence or persistance. C4 and C3 levels were $0.05 \mathrm{~g} / \mathrm{L}$ (normal values $0.18 \mathrm{~g} / \mathrm{L}$ to $0.36 \mathrm{~g} / \mathrm{L}$ ) and 1.00 (normal values $0.80 \mathrm{~g} / \mathrm{L}$ to $2.00 \mathrm{~g} / \mathrm{L}$ ), respectively. Both triglyceride and albumin levels remained normal. By 23 months post-transplant, creatinine had increased to $126 \mu \mathrm{mol} / \mathrm{L}$ (normal values $45 \mu \mathrm{mol} / \mathrm{L}$ to $125 \mu \mathrm{mol} / \mathrm{L}$ ) and urinalysis showed $3+$ proteinuria. Protein to creatinine ratio had increased to $428 \mathrm{mg} / \mathrm{mmol}$ (normal values less than $13 \mathrm{mg} / \mathrm{mmol}$ ) (calculated protein excretion $5.7 \mathrm{~g} /$ day at 24 months post-transplant). The urine to creatinine ratio is known to accurately and reliably estimate the level of proteinuria, as measured by $24 \mathrm{~h}$ urine protein excretion $(0.93$ by linear regression), with high sensitivity (97\% to $99 \%$ ) and specificity (95\% to $99 \%$ ) (8).

Because of his deteriorating renal function and proteinuria, HCV antiviral combination therapy with ribavirin and IFN- $\alpha 2 b$ was restarted 23 months post-transplant at doses of $3 \mathrm{mU}$ taken subcutaneously three times a week and $200 \mathrm{mg}$ taken orally twice a week, respectively, for a total course of 24 weeks. Despite ongoing hemolytic anemia requiring blood transfusions every one to two weeks and an increase in his darbepoetin alfa (Aranesp, Amgen Canada Inc) dose, the patient's overall condition improved. Blood pressure stabilized to approximately $130 / 70 \mathrm{mmHg}$, ALT remained normal and the vasculitic rash completely disappeared. By the end of 24 weeks of combination treatment, HCV RNA remained undetectable (detection limit of assay $600 \mathrm{HCV} \mathrm{IU} / \mathrm{mL}$ ) and continued to be undetectable 24 weeks after treatment.

With IFN and ribavirin treatment, the patient's renal function also stabilized (Figure 1). Before this treatment period (within the same month), $8 \mathrm{mg}$ daily of candesartan (Atacand, AstraZeneca Canada Inc) was taken orally which was adjusted up to $16 \mathrm{mg}$ daily taken orally. Over the 24 week combination treatment course, his creatinine level remained stable, ranging from $126 \mu \mathrm{mol} / \mathrm{L}$ at the beginning of treatment to $133.25 \mu \mathrm{mol} / \mathrm{L}$ 


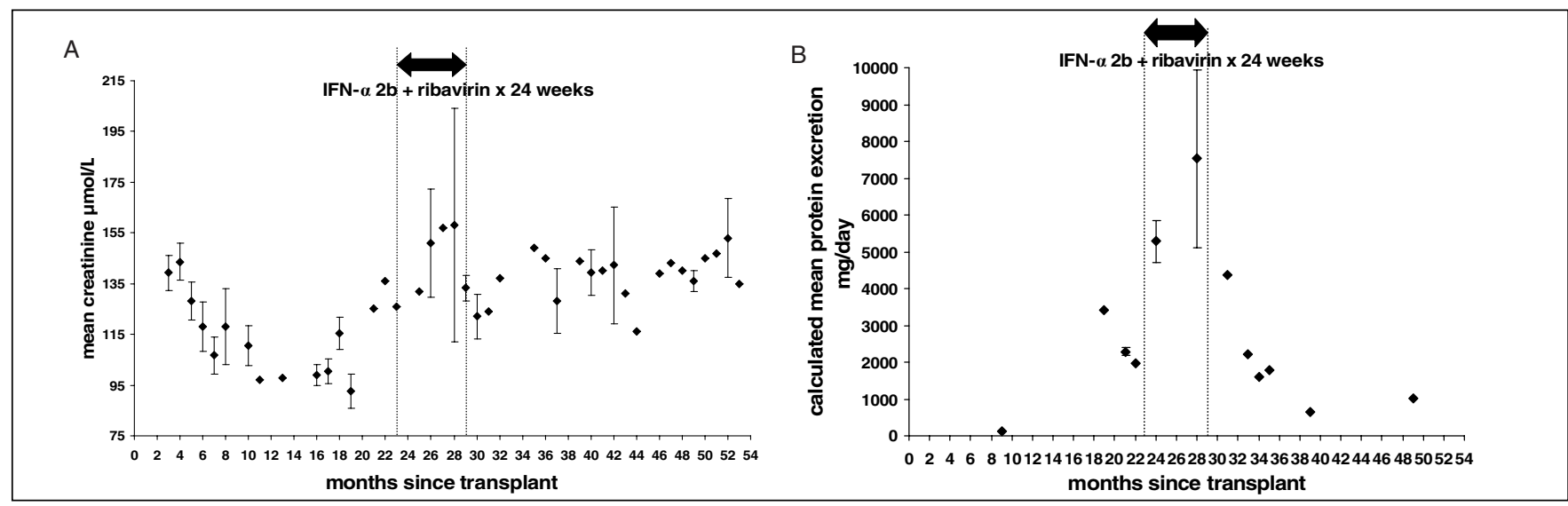

Figure 1) Mean \pm SD creatinine levels for each month (or single creatinine value if only one measured for the month) used as markers of renal function (A) and calculated mean \pm SD protein excretion (assuming creatinine excretion is $0.19 \mathrm{mmol} / \mathrm{kg} /$ day) (B). Interferon-alpha (IFN- $\alpha$ ) and ribavirin combination therapy was given between 23 and 29 months after renal transplant. A Stabilization in renal function after renal transplantation, with IFN- $\alpha$ and ribavirin treatment of recurrent hepatitis C. B Improvement in urinary protein excretion after renal transplantation with IFN- $\alpha$ and ribavirin treatment of recurrent hepatitis $\mathrm{C}$

(normal values $45 \mu \mathrm{mol} / \mathrm{L}$ to $125 \mu \mathrm{mol} / \mathrm{L}$ ) after 24 weeks. One year later, his creatinine remained stable at approximately $140 \mu \mathrm{mol} / \mathrm{L}$. Furthermore, there was a decrease in urinary protein excretion. Before treatment, his urinalysis consistently showed $3+$ proteinuria and a protein to creatinine ratio between $148.98 \mathrm{mg} / \mathrm{mmol}$ to $256.16 \mathrm{mg} / \mathrm{mmol}$ (normal values less than $13 \mathrm{mg} / \mathrm{mmol}$ ) (calculated protein excretion $1.98 \mathrm{~g} /$ day to $3.41 \mathrm{~g}$ /day). By five months after the end of treatment this ratio was $120.71 \mathrm{mg} / \mathrm{mmol}$ (calculated protein excretion $1.60 \mathrm{~g} /$ day) and five months later it was $47.46 \mathrm{mg} / \mathrm{mmol}$ (calculated protein excretion $0.63 \mathrm{~g} /$ day). The protein to creatinine ratio has remained stable for two years and two months after antiviral treatment was initiated. At present, the patient continues on fosinopril, candasartan, tacrolimus, mycophenolate mofetil and prednisone immunosuppression and his serum HCV RNA is still undetectable. Despite this, his cryoglobulinemia has persisted. One year after treatment was completed and as of follow-up at four years post-transplant, cryoglobulinemia type II, as detected by cryoglobulin qualitative electrophoresis, persists with its associated vasculitic rash on the lower extremities.

\section{DISCUSSION}

$\mathrm{HCV}$-associated renal disease can occur in both native and transplanted kidneys. These diseases commonly include membraneous nephropathy and MPGN with or without mixed cryoglobulinemia. In the HCV renal transplant population, recurrent MPGN glomerulopathy presents as proteinuria and renal graft failure (9). The patient described here was diagnosed with HCV following his diagnosis of MPGN with mixed cryoglobulinemia in his native kidneys. HCV load decreased with treatment, as did his symptoms of cryoglobulinemia, suggesting that HCV was the cause of his renal dysfunction. After renal transplantation, despite temporary improvements in creatinine plasma levels, proteinuria persisted and allograft biopsy was consistent with recurrence of his MPGN. HCV kidney disease is more commonly seen in transplant (both renal or hepatic) recipients than in the native kidneys of HCV-positive individuals $(9,10)$. This is thought to be a result of higher HCV RNA levels secondary to the immunosuppression, which in turn leads to increased viral complex deposition in the glomerulus (11). Being HCV-positive is considered to be an independent risk factor for reduced renal allograft survival and patient death (12).

Renal transplant is still the best therapy for end-stage renal disease patients on renal replacement therapy who are known to be HCV-positive (12). The prevention of $\mathrm{HCV}$-associated glomerulonephritis with pretransplant virus elimination remains the standard of therapy but results are suboptimal, especially in genotype 1 , because only PEGIFN- $\alpha$ monotherapy can be used. Current results suggest that in these individuals, SVR can only be obtained in $13 \%$ to $21 \%$ (3). In nonresponders or in those who relapse after cessation of therapy, there is often disease recurrence after cessation of therapy or post-transplant. In the transplant population, data for IFN- $\alpha$ use are limited. Reports indicate induction of steroid-resistant renal allograft rejection when initially used for prevention of cytomegalovirus infection shortly after renal transplantation (13). In this small placebo-controlled trial, six of 21 patients receiving low-dose recombinant IFN- $\alpha$ 2C compared with zero of 19 patients receiving placebo, in addition to their cyclosporine and methylprednisolone immunosuppression, suffered irreversible transplant rejection (13). To date, there is no literature with respect to PEGIFN- $\alpha$ treatment and renal transplant rejection. Acute renal allograft rejection is well-documented in individuals with $\mathrm{HCV}$, treated with IFN- $\alpha$, with an incidence of between $15 \%$ and $73 \%$ (14). Table 1 summarizes the reported experience with IFN- $\alpha$ therapy in the early posttransplant period. An exceptionally high incidence of acute rejection and graft loss was seen. Chan et al (15) suggested that if IFN- $\alpha$ is given, it should not be given in the early transplant period, and that patients should have stable renal function when the drug is started. Ichikawa et al (16), however, described a case of acute renal allograft rejection after IFN treatment was started 17 months post-transplant.

There are two double-blind trials in which a higher incidence of renal allograft dysfunction was not seen after initiation of IFN treatment $(17,18)$. These studies used lower doses of IFN as cytomegalovirus prophylaxis in renal transplant recipients. With the available literature, it would appear that the risk of renal allograft rejection is increased and a risk benefit decision has to be made individually, taking into 
TABLE 1

The use of interferon (IFN) for hepatitis $\mathrm{C}$ virus (HCV) and renal allograft rejection

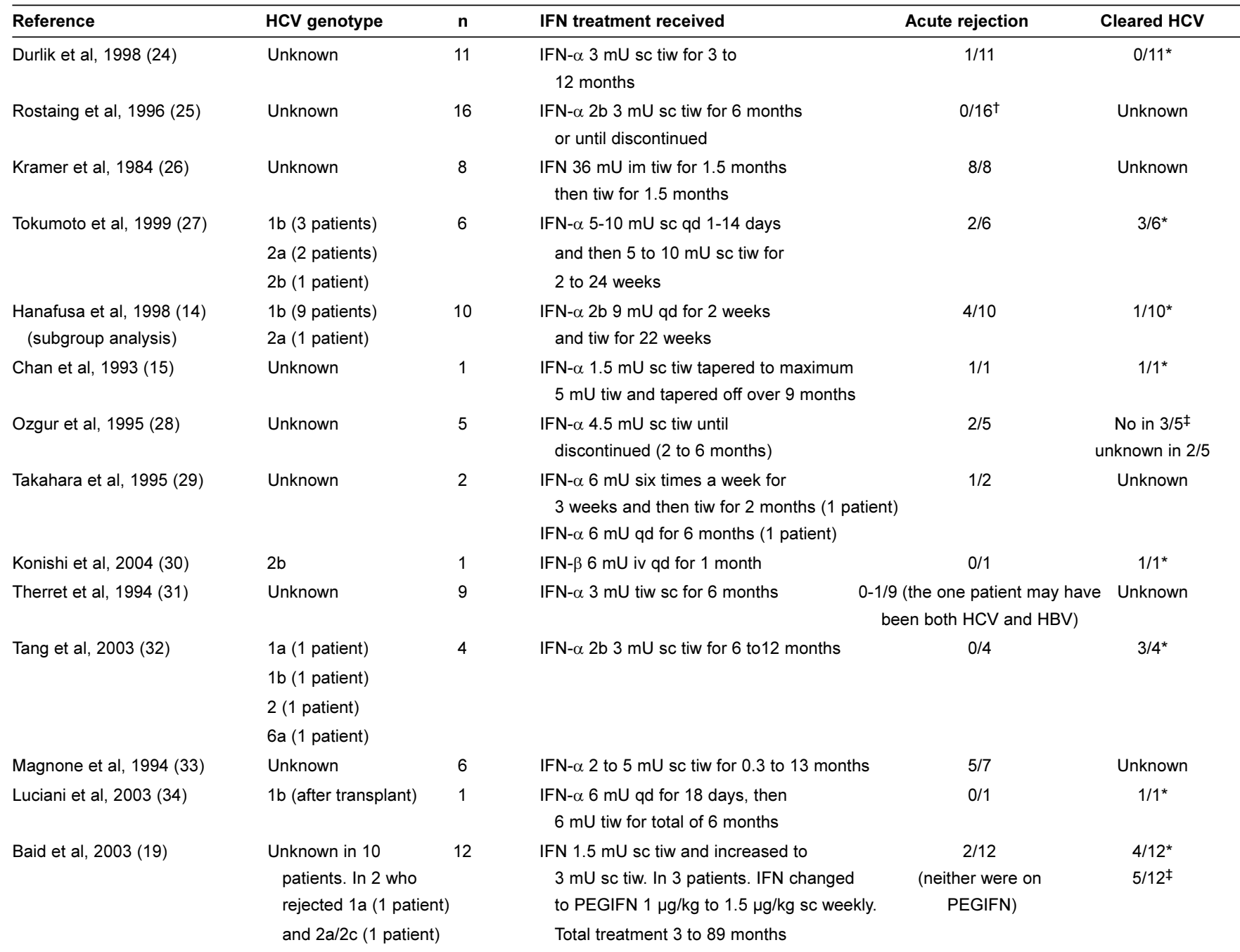

Patients documented as being hepatitis B virus (HBV) positive in addition to HCV positive are not included. Patients who received a combined liver and renal transplant are not included. *HCV clearance as documented by undetectable HCV viral load; ${ }^{*}$ six of 16 patients in Rostaing et al (25) were documented as having acute renal failure that could not be classified as acute rejection by the Banff criteria; nine of 16 patients also discontinued IFN- $\alpha$ due to side effects; $¥ H C V$ clearance as documented by liver biopsy and/or biochemical response. im Intramuscular; iv Intravenously; PEG Pegylated; qd Daily; sc Subcutaneously; tiw Three times a week

account the likelihood of response (HCV genotype versus the patients individual risk of rejection). One might expect similar results with PEGIFN as with IFN; however, there has only been one study to date looking for renal allograft rejection after PEGIFN treatment. As shown in Table 1, the present study switched three patients from IFN to PEGIFN during treatment and none of those three developed renal allograft rejection (19). It is possible that with today's more potent immunosuppressive agents that the risk of rejection and graft loss may be less.

Interestingly, despite the patients normalization of kidney function and sustained clearance of $\mathrm{HCV}$, his cryoglobulinemia, as determined by qualitative cryoglobulin electrophoresis, with associated vasculitic lesions persists. Notwithstanding a welldocumented association between HCV and cryoglobulinemia (20), there are reports of HCV clearance and ongoing cryoglobulinemia. Similar to our patient, Yamabe et al (21) presented a case of HCV clearance with documented SVR, improvement of MPGN on renal biopsy and continuation of cryoglobulinemia after a two-month intense course of standard IFN- $\alpha$ treatment
(10 mU subcutaneously daily for two weeks followed by $2 \mathrm{mU}$ three times daily for six weeks ) in a 42 -year-old man. Sarac et al (22) suggested that a higher dosage and longer course of IFN treatment ( $3 \mathrm{mU}$ taken subcutaneously twice a week, increased to $10 \mathrm{mU}$ taken subcutaneously daily for two weeks followed by $10 \mathrm{mU}$ taken subcutaneously twice a week for six weeks, for a total duration of treatment of 7.5 months) would be needed to clear the cryoglobulins, consistent with the logic that the disappearance of anti-HCV antibodies would be slower than that of HCV RNA (21). Alternatively, it has been reported that there may be persistence of HCV RNA including replicative intermediates in peripheral blood mononuclear cells using highly sensitive assays (23), and this may fuel the persistence of cryoglobulinemia.

\section{SUMMARY}

We present a case of deteriorating renal function and proteinuria due to recurrent MPGN in a HCV-positive renal allograft recipient who was successfully treated with a post-transplant course 
of IFN- $\alpha$ and ribavirin combination therapy. Despite HCV clearance, which has been sustained for over two years, symptomatic cryoglobulinemia continues. This case illustrates that carefully selected patients with $\mathrm{HCV}$ postrenal transplant can be

\section{REFERENCES}

1. Morales JM. Hepatitis $\mathrm{C}$ virus infection and renal disease after renal transplantation. Transplant Proc 2004;36:760-2.

2. Manns MP, McHutchison JG, Gordon SC, et al. Peginterferon alfa-2b plus ribavirin compared with interferon alfa- $2 \mathrm{~b}$ plus ribavirin for initial treatment of chronic hepatitis $\mathrm{C}$ : A randomised trial. Lancet 2001;358:958-65.

3. Fried MW, Shiffman ML, Reddy KR, et al. Peginterferon alfa-2a plus ribavirin for chronic hepatitis $\mathrm{C}$ virus infection. N Engl J Med 2002;347:975-82.

4. Fabrizi F, Martin P, Ponticelli C. Hepatitis C virus infection and renal transplantation. Am J Kidney Dis 2001;38:919-34.

5. Garnier JL, Chevallier P, Dubernard JM, Trepo C, Touraine JL, Chossegros P. Treatment of hepatitis $\mathrm{C}$ virus infection with ribarivin in kidney transplant patients. Transplant Proc 1997;29:783.

6. Brushfeld A, Stahle L, Andersson J, Schvarcz R. Ribavirin treatment in dialysis patients with chronic hepatitis $C$ virus infection - A pilot study. J Viral Hepat 2001;8:287-92.

7. Brushfeld A, Lindahl K, Stahle L, Soderberg M, Schvarcz R. Interferon and ribarivin treatment in patients with hepatitis Cassociated renal disease and renal insufficiency. Nephrol Dial Transplant 2003;18:1573-80.

8. Steinhauslin F, Wauters JP. Quantitation of proteinuria in kidney transplant patients: Accuracy of the urinary protein/creatinine ratio. Clin Nephrol 1995;43:110-5.

9. Roth D, Cirocco R, Zucker K, et al. De novo membranoproliferative glomerulonephritis in hepatitis $\mathrm{C}$ virus-infected renal allograft recipients. Transplantation 1995;59:1676-82.

10. Cantarell MC, Charco R, Capdevila L, et al. Outcome of hepatitis $\mathrm{C}$ virus-associated membranoproliferative glomerulonephritis after liver transplantation. Transplantation 1999;68:1131-4.

11. Burstein DM, Rodby RA. Membranoproliferative glomerulonephritis associated with hepatitis C virus infection. J Am Soc Nephrol 1993;4:1288-93.

12. Meyers CM, Seeff LB, Stehman-Breen CO, Hoofnagle JH. Hepatitis $C$ and renal disease: An update. Am J Kidney Dis 2003;42:631-57.

13. Kovarik J, Mayer G, Pohanka E, et al. Adverse effect of low-dose prophylactic human recombinant leukocyte interferon-alpha treatment in renal transplant recipients. Cytomegalovirus infection prophylaxis leading to an increased incidence of irreversible rejection. Transplantation 1988;45:402-5.

14. Hanafusa T, Ichikawa Y, Kishikawa H, et al. Retrospective study on the impact of hepatitis $\mathrm{C}$ virus infection on kidney transplant patients over 20 years. Transplantation 1998;66:471-6.

15. Chan TM, Lok AS, Cheng IK, Ng IO. Chronic hepatitis C after renal transplantation. Transplantation 1993;56:1095-8.

16. Ichikawa Y, Kyo M, Hanafusa T, et al. A 20-year case study of a kidney transplant recipient with chronic active hepatitis $\mathrm{C}$ : Clinical course and successful treatment for late acute rejection induced by interferon therapy. Transplantation 1998;65:134-8.

17. Hirsch MS, Schooley RT, Cosimi AB, et al. Effects of interferonalpha on cytomegalovirus reactivation syndromes in renaltransplant recipients. N Engl J Med 1983;308:1489-93. considered for treatment, provided adequate immunosuppression is maintained and they are carefully monitored. Furthermore, cryoglobulinemia-related complications may be reduced, but not completely eliminated, with viral clearance.

18. Lui SF, Ali AA, Grundy JE, Fernando ON, Griffiths PD, Sweny P. Double-blind, placebo-controlled trial of human lymphoblastoid interferon prophylaxis of cytomegalovirus infection in renal transplant recipients. Nephrol Dial Transplant 1992;7:1230-7.

19. Baid S, Tolkoff-Rubin N, Saidman S, et al. Acute humoral rejection in hepatitis $\mathrm{C}$-infected renal transplant recipients receiving antiviral therapy. Am J Transplant 2003;3:74-8.

20. Misiani R, Bellavita P, Fenili D, et al. Interferon alfa-2a therapy in cryoglobulinemia associated with hepatitis $\mathrm{C}$ virus. N Engl J Med 1994:330:751-6.

21. Yamabe H, Johnson RJ, Gretch DR, et al. Membranoproliferative glomerulonephritis associated with hepatitis $\mathrm{C}$ virus infection responsive to interferon-alpha. Am J Kidney Dis 1995;25:67-9.

22. Sarac E, Bastacky S, Johnson JP. Response to high-dose interferonalpha after failure of standard therapy in MPGN associated with hepatitis C virus infection. Am J Kidney Dis 1997:30:113-5.

23. Radkowski M, Gallegos-Orozco JF, Jablonska J, et al. Persistence of Hepatitis $\mathrm{C}$ virus in patients successfully treated for chronic Hepatitis C. Hepatology 2005;41:106-14.

24. Durlik M, Gaciong Z, Rowinska D, et al. Long-term results of treatment of chronic hepatitis B,C and D with interferon-alpha in renal allograft recipients. Transpl Int 1998:11(Suppl 1):135-9.

25. Rostaing L, Modesto A, Baron E, Cisterne JM, Chabannier MH, Durand D. Acute renal failure in kidney transplant patients treated with interferon alpha $2 \mathrm{~b}$ for chronic hepatitis $\mathrm{C}$. Nephron 1996;74:512-6.

26. Kramer P, ten Kate FW, Bijnen AB, Jeekel J, Weimar W. Recombinant leucocyte interferon $\mathrm{A}$ induces steroid-resistant acute vascular rejection episodes in renal transplant recipients. Lancet 1984;1:989-90.

27. Tokumoto T, Tanabe K, Ishikawa T, et al. Effect of interferon-alpha treatment in hemodialysis patients and renal transplant recipients with chronic hepatitis C. Transplant Proc 1999;31:2887-9.

28. Ozgur O, Boyacioglu S, Telatar H, Haberal M. Recombinant alpha-interferon in renal allograft recipients with chronic hepatitis C. Nephrol Dial Transplant 1995;10:2104-6.

29. Takahara S, Kakimoto K, Kokado Y, et al. Interferon-alpha therapy for chronic active hepatitis type $\mathrm{C}$ after renal transplantation and allograft rejection. Int Urol Nephro 1995;27:479-85.

30. Konishi I, Horiike N, Mitchitaka K, et al. Renal transplant recipient with chronic hepatitis $C$ who obtained sustained viral response after interferon-beta therapy. Intern Med 2004;43:931-4.

31. Therret E, Pol S, Legendre CH, Gagnadoux MF, Cavalcanti R, Kreis H. Low-dose recombinant leukocyte interferon-alpha treatment of hepatitis $\mathrm{C}$ viral infection in renal transplant recipients. A pilot study. Transplantation 1994;58:625-628.

32. Tang S, Cheng IK, Leung VK, et al. Successful treatment of hepatitis $\mathrm{C}$ after kidney transplantation with combined interferon alpha-2b and ribavirin. J Hepatol 2003;39:875-8.

33. Magnone M, Holley JL, Shapiro R, et al. Interferon-alpha-induced acute renal allograft rejection. Transplantation 1994;59:1068-70.

34. Luciani G, Bossola M, Muscaritoli M, et al. Sustained response with negative serum HCV-mRNA and disappearance of antibodies after interferon-alpha therapy in a kidney transplant recipient with chronic active viral hepatitis C. J Nephrol 2003;16:417-20. 


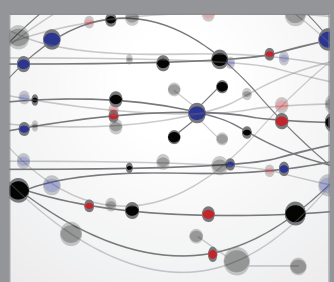

The Scientific World Journal
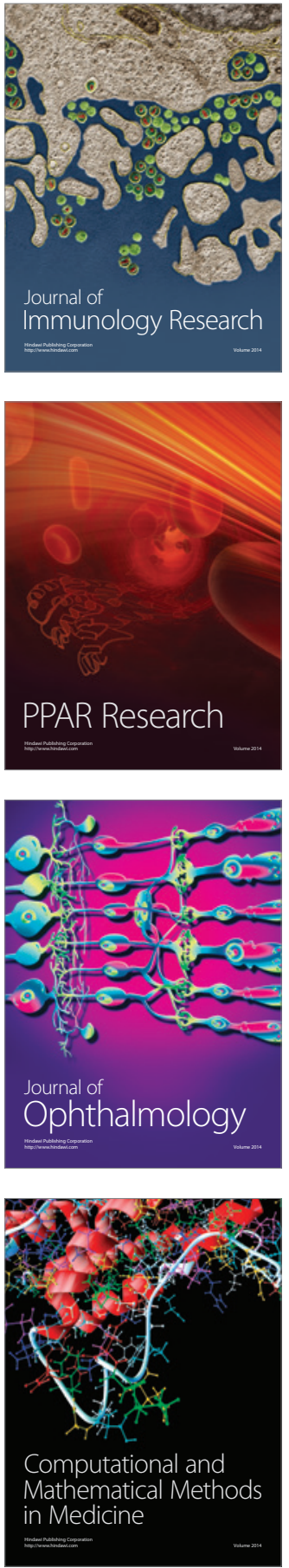

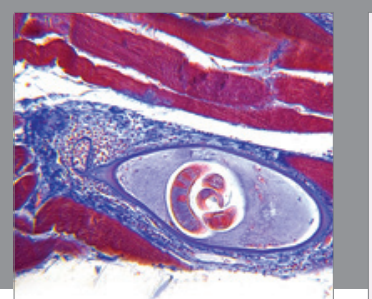

Gastroenterology Research and Practice

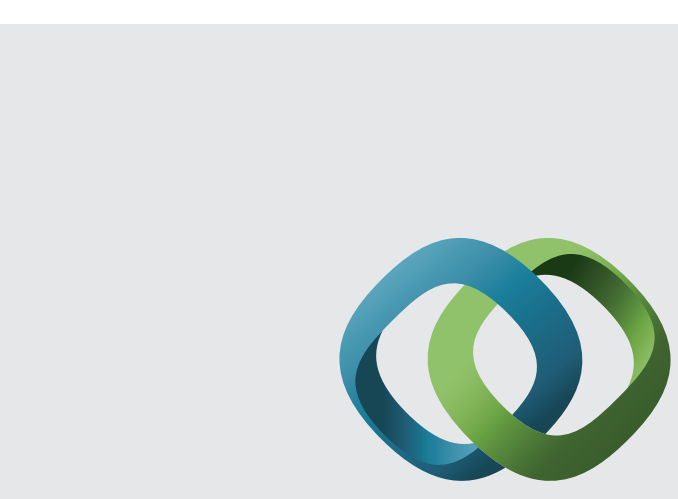

\section{Hindawi}

Submit your manuscripts at

http://www.hindawi.com
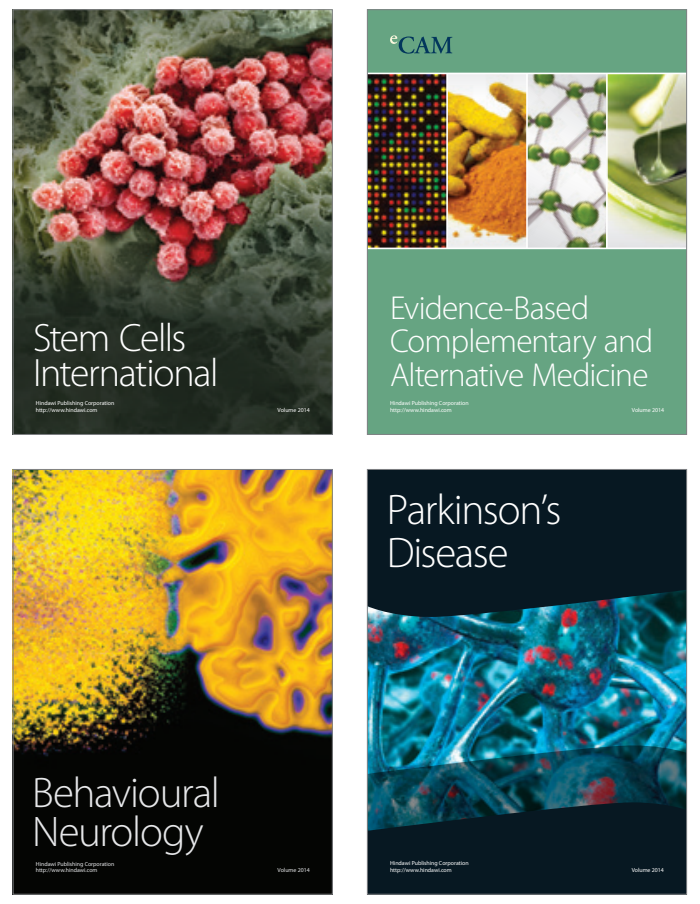
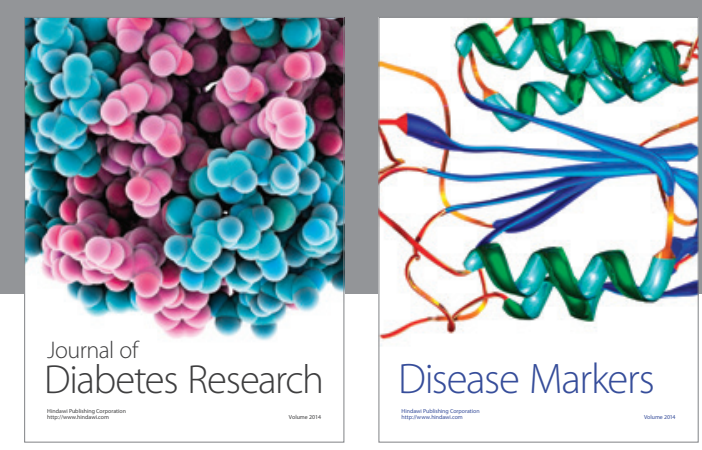

Disease Markers
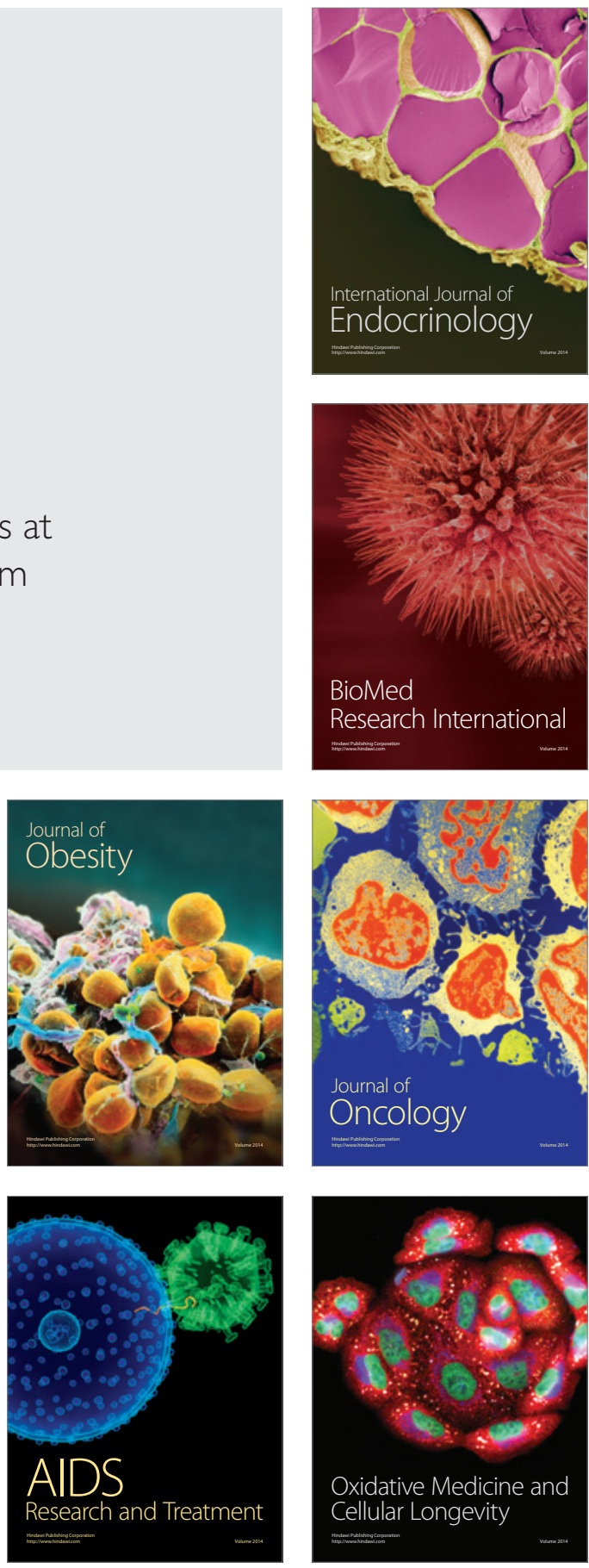